Molekul, Vol. 9. No. 2. November, 2014: 128 - 135

\title{
EKSPLORASI BAKTERI KITINOLITIK DARI SAMPAH ORGANIK : ISOLASI DAN KARAKTRISASI ENZIM KITINASE
}

\section{EXPLORATION OF CHITINOLYTIC BACTERIA FROM ORGANIC WASTE: ISOLATION AND CHARACTERIZATION OF CHITINASE ENZYME}

\author{
Purkan*, Badi'atul Azizah, Afaf Baktir dan Sri Sumarsih \\ Departemen Kimia, Fakultas Sains dan Teknologi Universitas Airlangga \\ *e-mail: purkan@unair.ac.id
}

\begin{abstract}
ABSTRAK
Enzim kitinase banyak digunakan dalam bidang medis, makanan, bioteknologi dan lingkungan. Banyaknya kebutuhan enzim kitinase menuntut penyediannya yang murah dan melimpah dengan teknologi produksi yang sederhana. Penelitian ini bertujuan untuk isolasi mikroba kitinolitik dari cairan fermentasi sampah organik, produksi dan uji aktivitas enzim kitinase serta mengetahui karakteristik dari enzim kitinase. Isolasi mikroba telah dilakukan dengan metode spread plate. Aktivitas kitinase ditentukan secara kualitatif dengan pengukuran indeks kitinolitik dan secara kuantitatif dengan pengukuran absorbansi menggunakan spektrofotometer Uv-Vis pada panjang gelombang $660 \mathrm{~nm}$ berdasarkan banyaknya substrat kitin yang dihidrolisis oleh enzim kitinase. Satu dari beberapa isolat yang didapatkan, yaitu isolat A1 menunjukkan aktivitas kitinolitik tertinggi, yaitu sebesar 1,21. Hasil identifikasi mikrobiologi menunjukkan bahwa isolat A1 dinyatakan sebagai Pseudomonas pseudomallei. Bakteri ini mampu menghasilkan kitinase secara optimum pada jam ke 18 waktu fermentasi, dengan penambahan molase 0,5\% (b/v) dan $1 \%$ kitin $(\mathrm{b} / \mathrm{v})$ pada media produksinya. Kitinase yang dihasilkan $P$. pseudomallei menunjukkan aktivitas optimum pada suhu $50{ }^{\circ} \mathrm{C}$ dan $\mathrm{pH}$ sebesar 6 .
\end{abstract}

Kata kunci: Bakteri kitinolitik, Kitinase, Molase, Sampah organik

\begin{abstract}
Chitinase is an enzyme widely used in the medical field, food, biotechnology and environment. The high demand of chitinase enzyme requires improvement of its production using a simple technology to make its availability abundant and low price. The purposes of the research were to isolate chitinolytic microbe from liquid fermentation of organic waste, to produce chitinase enzyme and also to characterize the enzyme. Isolation of microbe has been done by spreading method of the liquid of organic waste on selective solid medium. Chitinase activity was conducted by determining of chitinolytic index from bacteria and quantitative assay using Uv-Vis Spectrophotometer at $660 \mathrm{~nm}$ based on the amount of substrate remain from chitin hydrolyzing proces. One of some isolates which obtained, namely A1 showed the highest chitinolytic activity with index score as 1,21 . The isolate A1 has been known as P. pseudomallei. The bacteria could produce chitinase at 18 hours of time fermentation which followed by addtion $0,5 \%$ (w./v) of molasses and $1 \%$ (w/v) of chitin in its production medium. The Chitinase of P. pseudomallei showed optimum activity at $50^{\circ} \mathrm{C}$ and $\mathrm{pH} 6$.
\end{abstract}

Keywords: Chitinolytic microbe, Chitinase, Molasses, Organic waste 


\section{PENDAHULUAN}

Kitin adalah suatu polisakarida, polimer linier yang tersusun dari $\beta-1,4-$ $\mathrm{N}$-asetil-glukosamin. Kitin merupakan biomassa yang sangat melimpah di alam, terbesar kedua setelah selulosa. Distribusi kitin banyak ditemukan pada kulit crustacea (kepiting, udang dan lobster), ubur-ubur, komponen struktural eksoskeleton insekta, dinding sel fungi (22-40\%), alga, nematode, kulit binatang dan tumbuhan (Kuddus and Ahmad, 2013). Beberapa bakteri dan fungi yang mempunyai aktivitas kitinolitik mampu mendegradasi kitin (Yurnaliza, dkk., 2008). Proses degradasi kitin melibatkan kerja enzim dan menghasilkan produk turunan kitin. Kitinase adalah enzim penghidrolisis kitin menjadi oligomernya seperti karboksimetil kitin, hidroksietil kitin, N-asetil-D-glukosamin dan etil kitin yang banyak dimanfaatkan untuk bidang medis dan makanan. $\mathrm{N}$-asetil-Dglukosamin, produk hidrolisis kitin banyak dimanfaatkan sebagai prebiotik, obat pengontrol kadar gula darah, suplemen, anti inflamasi dan sebagainya (Herdyastuti et al, 2009). Banyaknya kebutuhan enzim kitinase di berbagai bidang menuntut penyediannya yang melimpah dan murah dengan teknologi produksi yang sederhana.

Pengembangan dalam penyediaan kitinase memerlukan eksplorasi jenis-jenis mikroorganisme unggul penghasil enzim dengan sifatsifat unik, seperti termofilik, halo toleran, asido dan alkalofilik (Chern et $a l, 2004)$. Mikroba penghasil kitinase ini, umumnya dapat ditemukan di lingkungan ekstrim yang mengandung biomassa kitin, seperti lingkungan tanah, air tercemar, sampah, cangkang dan kulit binatang serta tumbuhan. Rostinawati (2008) berhasil mendapatkan bakteri penghasil kitinase dari air laut, sementara itu Herdyastuti (2009) telah berhasil mengsolasi bakteri kitinolitik dari tanah. Cairan hasil fermentasi sampah dapur yang ditambah dengan molase menunjukkan aktivitas enzim kitinase. Fenomena ini menunjukkan bahwa terdapat mikroorganisme penghasil kitinase di dalam cairan fermentasi tersebut. Pengembangan produksi kitinase memerlukan isolat murni yang dapat menghasilkan enzim dalam jumlah banyak. Artikel ini melaporkan tentang skrining dan isolasi mikroba kitinolitik serta karakterisasi enzim kitinase yang dihasilkan.

\section{METODE PENELITIAN}

\section{Sampel Penelitian}

Cairan hasil fermentasi sampah
dapur dan molase, yang telah
menunjukkan aktivitas kitinase,
digunakan sebagai sampel untuk
mendapatkan mikroba kitinolitik.

\section{Bahan dan Alat}

Bahan-bahan yang digunakan dalam penelitian ini terdiri atas molase, glukosa, $\mathrm{HCl}, \mathrm{NaOH}$, etanol 95\%, $\mathrm{KH}_{2} \mathrm{PO}_{4}, \quad \mathrm{Na}_{2} \mathrm{HPO}_{4} .7 \mathrm{H}_{2} \mathrm{O}, \quad \mathrm{NaH}_{2} \mathrm{PO}_{4}$, $\mathrm{C}_{6} \mathrm{H}_{8} \mathrm{O}_{7}, \mathrm{MgSO}_{4}, \mathrm{NaCl}, \mathrm{CaCl}_{2}$, bacto tryptone, kitin, bacto agar, congo red, yeast ekstrak, akuades. Sementara alatalat yang digunakan terdiri atas seperangkat alat gelas, termometer, autoklaf, pipet mikro, Eppendorf, inkubator, waterbath (SYK-382SM), lemari pendingin (Thosiba Glacio), dan rotary shaker. Instrumen yang digunakan adalah timbangan analitik (Mettler Toledo), sentrifuga, spektrofotometer UV-VIS (UV-1800 Shimadzu), laminar air flow cabinet, dan pH meter (Mettler Toledo AL-204).

\section{Prosedur Kerja}

\section{Isolasi dan identifikasi mikroba penghasil enzim kitinase}

Isolasi mikroba kitinolitik dari cairan fermentasi sampah organik dilakukan dengan mengambil sebanyak 
$100 \mu \mathrm{L}$ cairan fermentasi lalu diencerkan 1000x. Kemudian ditanam dalam media padat yang tersusun atas $0,02 \%(\mathrm{~b} / \mathrm{v})$ yeast ekstrak, $0,1 \quad \% \quad(\mathrm{~b} / \mathrm{v}) \quad \mathrm{KH}_{2} \mathrm{PO}_{4}$, $0,24 \%$ (b/v) $\mathrm{MgSO}_{4}, 0,1 \%$ (b/v) $\mathrm{NaCl}$, $0,01 \%$ (b/v) $\mathrm{CaCl}_{2}, 0,5 \%$ (b/v) bacto trypton, $1 \%(\mathrm{~b} / \mathrm{v})$ glukosa dan $1,8 \%(\mathrm{~b} / \mathrm{v})$ bacto agar, dengan spreader dan kemudian diinkubasi pada suhu $37{ }^{\circ} \mathrm{C}$ selama 16 jam. Koloni yang tumbuh ditanam kembali ke media padat yang mengandung $1 \% \quad(\mathrm{~b} / \mathrm{v})$ kitin, lalu diinkubasi selama 7 hari untuk mengetahui aktivitas kualitatif kitinolitiknya berdasarkan zona bening yang terbentuk. Bakteri dengan indeks kitinolitik terbesar kemudian diidentifikasi secara makroskopis, mikroskopis, dan uji biokimia untuk penentuan jenis mikroba.

\section{Pembuatan kurva pertumbuhan}

Satu koloni terpilih dimasukkan ke dalam $20 \mathrm{~mL}$ media cair (komposisinya sama dengan media padat tetapi tanpa agar) dan diinkubasi semalam pada suhu $37{ }^{\circ} \mathrm{C}$ dan penggoyangan pada kecepatan $150 \mathrm{rpm}$. Sebanyak $1 \% \quad(\mathrm{v} / \mathrm{v})$ kultur yang diperoleh, dipindahkan kembali ke dalam $20 \mathrm{~mL}$ media pertumbuhan cair dalam labu Erlemenyer $100 \mathrm{~mL}$, lalu diinkubasi pada kondisi yang sama. Selanjutnya dilakukan pengukuran OD (Optical Density) dengan dilakukan sampling sebanyak $3 \mathrm{~mL}$ setiap selang waktu 2 jam sampai nilai OD menunjukkan penurunan yang jelas. OD diukur dengan menggunakan spektrofotometer UV-VIS pada $\lambda 600$ nm. Kemudian dibuat kurva pertumbuhan dengan memplot nilai $\mathrm{OD}_{600 \mathrm{~nm}}$ terhadap waktu.

\section{Produksi Kitinase}

\section{Optimum waktu produksi}

Inokulum sebanyak $200 \mu \mathrm{L}$ ditambahkan ke dalam $20 \mathrm{~mL}$ media produksi (komposisinya sama dengan media cair, tetapi ditambah $1 \%(\mathrm{~b} / \mathrm{v})$ kitin), kemudian diinkubasi pada suhu 37 ${ }^{\circ} \mathrm{C}$ dan penggoyangan dengan kecepatan 150 rpm. Setiap 3 jam disampling sebanyak $2 \mathrm{~mL}$ kultur sel. Sampling dimulai dari jam ke-0 sampai jam ke-33. Kemudian disentrifugasi pada suhu $4{ }^{\circ} \mathrm{C}$ dengan kecepatan $10.000 \mathrm{rpm}$ selama 10 menit, supernatan yang diperoleh merupakan ekstrak kasar enzim kitinase.

\section{Optimasi kadar molase}

Sebanyak $200 \mu \mathrm{L}$ inokulum ditambahkan ke dalam $20 \mathrm{~mL}$ media produksi dengan variasi konsentrasi molase $0 ; 0,2 ; 0,4 ; 0,5 ; 0,6 ; 0,8$ dan $1 \%$ (b/v). Kultur kemudian diinkubasi pada suhu $37{ }^{\circ} \mathrm{C}$ dengan penggoyangan kecepatan $150 \mathrm{rpm}$ selama waktu produksi optimal yang diperoleh dari data optimasi waktu produksi. Selanjutnya dilakukan uji aktivitas kitinase terhadap supernatan yang dihasilkan.

\section{Uji aktivitas enzim kitinase}

Sebanyak $275 \mu \mathrm{L}$ ekstrak kasar enzim ditambah dengan $1650 \mu \mathrm{L}$ substrat $1 \%(\mathrm{~b} / \mathrm{v})$ koloidal kitin dalam tabung, lalu diinkubasi pada $37{ }^{\circ} \mathrm{C}$ selama 20 menit. Pada kontrol, $275 \mu \mathrm{L}$ ekstrak kasar enzim yang digunakan dipanaskan terlebih dahulu pada $100{ }^{\circ} \mathrm{C}$ selama 20 menit. Hasil reaksi selanjutnya diukur absorbansinya dengan Spektrofotometer UV-Vis pada $\lambda 660$ nm.

$\begin{array}{cccr}\text { Definisi } & 1 \mathrm{U} & \text { (unit) } & \text { aktivitas } \\ \text { adalah } & \text { jumlah } & \text { enzim } & \text { yang }\end{array}$ menghidrolisis substrat kitin $1 \mathrm{mg} / \mathrm{mL}$ per menit dalam kondisi percobaan. Dalam hal ini, aktivitas enzim kitinase dihitung berdasarkan banyaknya substrat kitin yang dihidrolisis oleh enzim kitinase menjadi $\mathrm{N}$-asetil glukosamin. 


\section{Karakterisasi Enzim Kitinase}

\section{Penentuan pH optimum}

Dilakukan uji aktivitas ekstrak kitinase dengan menggunakan substrat kitin yang dilarutkan dalam berbagai $\mathrm{pH}$, yaitu 3,4,5,6,7 dan 8. Pengaturan $\mathrm{pH} 3-5$ dilakukan dengan bufer sitrat fosfat sedangkan $\mathrm{pH}$ 6-8 menggunakan bufer fosfat. Nilai $\mathrm{pH}$ yang memberikan aktivitas kitinase tertinggi ditetapkan sebagai $\mathrm{pH}$ optimum.

\section{Penentuan suhu optimum}

Dilakukan uji aktivitas ekstrak kitinase pada suhu yang berbeda-beda, yaitu 30, 37, 40, 50, 60 dan $70{ }^{\circ} \mathrm{C}$. Setelah inkubasi selesai, kemudian diukur absorbansinya pada panjang gelombang 660 nm. Suhu yang memberikan aktivitas kitinase tertinggi ditetapkan sebagai suhu optimum

\section{HASIL DAN PEMBAHASAN}

\section{Isolasi dan Identifikasi Mikroba Kitinolitik}

Kitinolitik merupakan proses degradasi biomassa kitin yang dilakukan oleh kerja sel mikroba. Mikroba yang dapat melakukan proses ini adalah jenis mikroba yang mampu menghasilkan kitinase, yaitu suatu jenis enzim yang mampu menghidrolisis makromolekul kitin yang terdapat di sekitar lingkungan mikroba kitinolitik tumbuh. Kitinase tergolong pada jenis enzim depolimerase yang berarti kerjanya menyederhanakan polimer kitin menjadi oligomer dan $\mathrm{N}$ asetil glukosamin sehingga dapat diserap oleh mikroba sebagai nutrien untuk menjalankan proses metabolisme dan pertumbuhannya.

Skrining mikroba kitinolitik dari cairan fermentasi sampah organik telah dilakukan dengan menebarkan kultur sel mikroba yang terdapat pada cairan fermentasi tersebut pada media agar kitin. Dari koloni-koloni mikroba yang ditumbuhkan pada media ini, terdapat beberapa koloni mikroba yang tumbuh disertai dengan daerah bening. Zona bening terbentuk akibat kerja mikroba yang mampu mensekresi kitinolitik dan selanjutnya digunakan untuk menghidrolisis kitin di lingkungan, sehingga memberikan penampakan bening di sekitar tempat tumbuhnya mikroba. Zona bening dapat dipertajam penampakkannya dengan menambahkan congo red pada media. Aktivitas kitinolitik tertinggi ditunjukkan oleh isolat mikroba A1 dengan indeks kitinolitik sebesar 1,21 (Gambar 1).

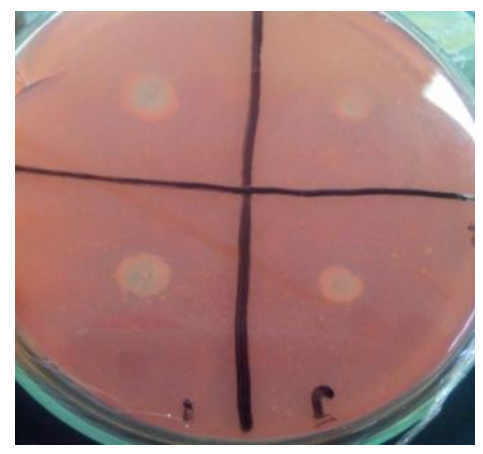

Gambar 1. Mikroba kitinolitik pada media kitin yang mengandung Congo red

Identifikasi genus dan strain mikroba isolat A1 juga telah dilakukan melalui uji makro dan mikroskopis serta uji biokimia pada Laboratorium Mikrobiologi, Fakultas Sains dan Teknologi, Universitas Airlangga. Hasil identifikasi menunjukkan bahwa isolat A1 tergolong sebagai bakteri $P$. pseudomallei. Sejumlah peneliti telah melaporkan kelompok bakteri penghasil kitinase, diantaranya adalah Pseudomonas, Aeromonas, Xanthomonas, Serratia, Cytophaga, Arthrobacter, dan Bacillus merupakan spesies bakteri kitinolitik (Vaidya et al, 2003)

\section{Pembuatan Kurva Pertumbuhan}

Informasi pola pertumbuhan bakteri $P$. pseudomallei diperlukan untuk mengetahui fase-fase pertumbuhan dari 
bakteri tersebut, sehingga dapat ditentukan fase logaritmik dimana suatu bakteri dapat digunakan sebagai bibit (inokulum) karena memiliki pertumbuhan yang optimal. Pertumbuhan $P$. pseudomallei menunjukkan fase lag pada jam ke 0 samapai 2 jam (Gambar 2).

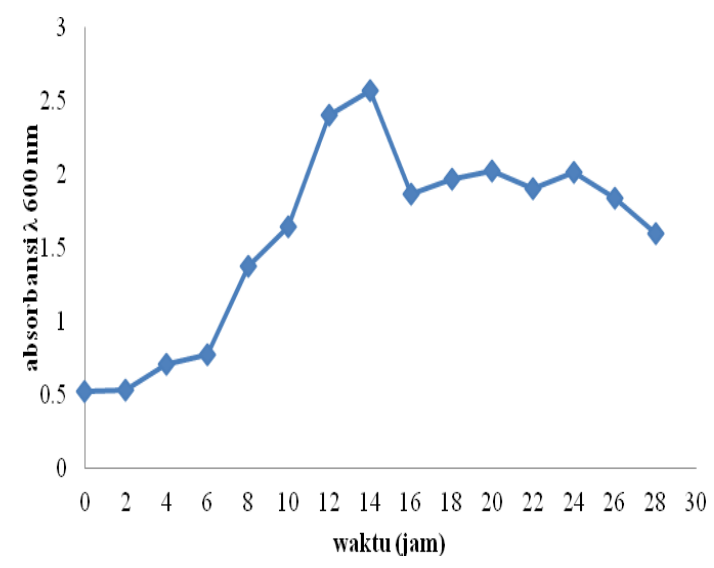

Gambar 2. Kurva pertumbuhan bakteri P. pseudomallei

Pada fase ini bakteri mengalami adaptasi. Kemudian fase logaritmik pada jam ke 4 sampai 12 jam, pada fase ini bakteri mengalami fase pertumbuhan cepat dimana massa dan volume sel meningkat karena nutrisi pada media tercukupi sehingga dapat tumbuh dengan optimal. Fase stasioner berada pada jam ke 12 sampai 14 jam, pada fase ini jumlah sel tidak mengalami peningkatan atau penurunan, kecepatan pertumbuhan sama dengan kecepatan kematian disebabkan karena kekurangan nutrien dan peningkatan produk limbah. Sedangkan fase kematian berada pada jam ke 16 sampai 28 jam, pada fase ini bakteri akan kehabisan nutrisi, jumlah sel akan menurun dan pada fase ini jumlah sel yang mati lebih banyak daripada sel yang hidup.

Inokulum untuk produksi kitinase diambil dari kultur pada fase logaritmik, yaitu pada jam ke 12-14 jam. Pada kondisi $P$. pseudomallei memiliki aktivitas metabolisme paling optimum dan aktif, dapat mensintesis bahan sel dengan cepat dalam jumlah konstan, sehingga sangat cocok digunakan sebagai bibit (inokulum) untuk produksi enzim.

\section{Produksi kitinase dari $P$. pseudomallei}

\section{Waktu produksi optimum}

Optimasi waktu produksi dilakukan untuk mengetahui waktu panen yang tepat selama proses produksi enzim kitinase, dimana $P$. pseudomallei menghasilkan kitinase dengan aktivitas tertinggi. Untuk menentukan waktu optimum, maka dilakukan produksi enzim pada 0 jam sampai 36 jam dengan selang waktu 3 jam dilakukan sampling untuk penentuan aktivitas kitinase yang dihasilkan. Aktivitas kitinase yang diperoleh dari supernatan kultur meningkat pada jam ke 0 sampai 18 jam, aktivitas enzim tertinggi berada pada 18 jam yang dinyatakan dengan nilai aktivitas enzim sebesar $0,3850 \mathrm{U} / \mathrm{mL}$ dan kemudian menurun pada $21 \mathrm{jam}$ sampai 36 jam (Gambar 3).

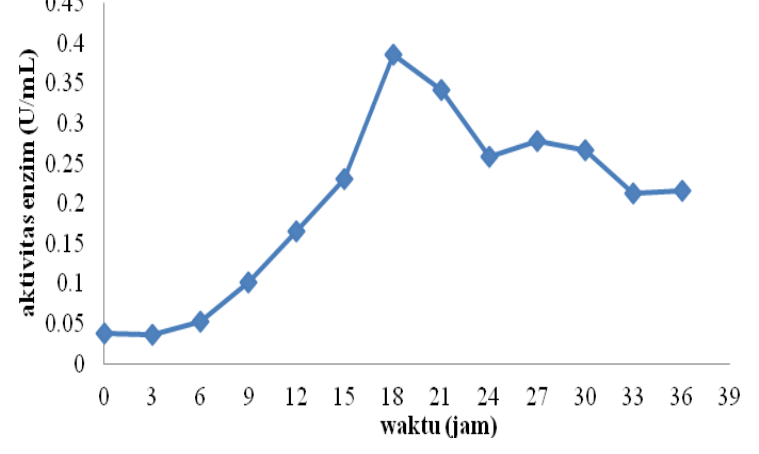

Gambar 3. Kurva aktivitas enzim kitinase terhadap watu produksi

Peningkatan aktivitas enzim menunjukkan bahwa semakin banyak substrat yang terhidrolisis. Aktivitas enzim kitinase terus meningkat dari 0 jam inkubasi hingga mencapai waktu inkubasi optimum, hal ini dapat terjadi karena pada 0 jam masih sedikit enzim yang bereaksi dengan substrat dan akan meningkat seiring dengan peningkatan 
waktu inkubasi hingga mencapai waktu inkubasi optimum. Setelah mencapai waktu optimum, aktivitas enzim menurun dikarenakan telah terjadi akumulasi produk hidrolisis yang selanjutnya dapat menghambat aktivitas enzim.

\section{Kadar molase optimum untuk produksi enzim kitinase}

Optimasi konsentrasi molase dilakukan untuk mengetahui konsentrasi molase optimum sehingga $P$. pseudomallei menghasilkan aktivitas kitinase tertinggi. Molase merupakan salah satu limbah yang dihasilkan industri gula, di dalam molase terkandung 40-60\% sukrosa, glukosa dan fruktosa dalam konsentrasi yang lebih rendah (Dumbrepatil, 2008). Molase berfungsi sebagai sumber karbon untuk nutrisi pertumbuhan bakteri. Penggunaan molase dalam media kitin bagi $P$. pseudomallei untuk produksi kitinase perlu dikendalikan. Molase difungsikan untuk mengantar $P$. pseudomallei mencapai sel dengan kualitas terbaik, sehingga ketika diinduksi dengan kitin, sel mensekresi enzim kitinase secara optimum.

Aktivitas kitinase meningkat pada media yang mengandung molase dengan konsentrasi $0 \%$ sampai $0,4 \%$ (b/v) (Gambar 4). Aktivitas tertinggi tercapai oleh adanya molase $0,5 \%(\mathrm{~b} / \mathrm{v})$ pada media, dengan aktivitas enzim sebesar 2,4800 U/mL. Aktivitas kitinase kemudian menurun pada media yang mengandung molase $0,6 \%$ sampai $1 \%$ (b/v). Meningkatnya aktivitas enzim pada konsentrasi molase $0 \%$ sampai $0,4 \%$ menunjukkan nutrisi yang dibutuhkan bakteri untuk hidup dan melakukan aktivitasnya masih tercukupi hingga mencapai optimum pada konsentrasi molase $0,5 \%$. Aktivitas yang mulai menurun setelah mencapai optimum yaitu pada konsentrasi molase
$0,6 \%$ hingga $1 \%$. Penurunan ini disebut sebagai efek represi katabolit, dimana molase kadar tinggi merepresi atau menghambat proses katabolisme kitin yang memerlukan hadirnya kitinase. Selama persedian gula sederhana dari molase masih tercukupi, maka sintesis enzim kitinase oleh $P$. pseudomallei dihambat.

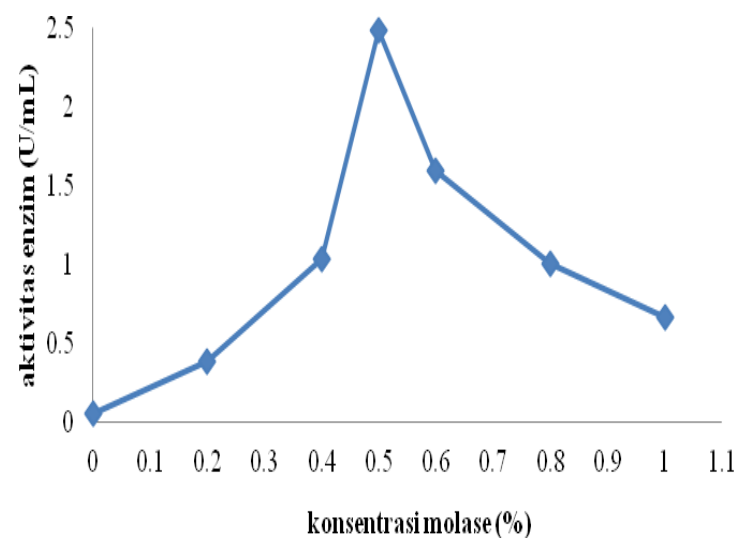

Gambar 4. Kurva produktifitas kitinase terhadap kadar molase

\section{Karakteristik Enzim Kitinase}

\section{pH optimum kitinase}

Setiap enzim memiliki $\mathrm{pH}$ optimum yang berbeda-beda, $\mathrm{pH}$ optimum adalah $\mathrm{pH}$ dimana enzim menghasilkan aktivitas tertinggi dalam mengkatalisis suatu reaksi. Adanya penurunan atau peningkatan aktivitas enzim kitinase setelah $\mathrm{pH}$ optimum disebabkan adanya perubahan keadaan ion enzim dan keadaan ion substrat. Perubahan kondisi ion enzim dapat terjadi pada residu asam amino yang berfungsi katalitik mengikat substrat atau residu asam amino yang berfungsi mempertahankan struktur tersier dan kuatener enzim aktif. Aktivitas enzim yang mengalami penurunan dapat dipulihkan dengan merubah kondisi reaksi enzimatik pada $\mathrm{pH}$ optimalnya. Pada $\mathrm{pH}$ tertentu perubahan muatan ion pada rantai samping yang dapat terionisasi dari residu asam amino enzim menjadi terlalu besar sehingga mengakibatkan perubahan struktur 
tersiernya. Hasil uji aktivitas enzim menunjukkan aktivitas kitinase $P$. pseudomallei tertinggi tercapai pada $\mathrm{pH}$ 6 dengan aktivitas sebesar 1,7768 U/mL (Gambar 5).

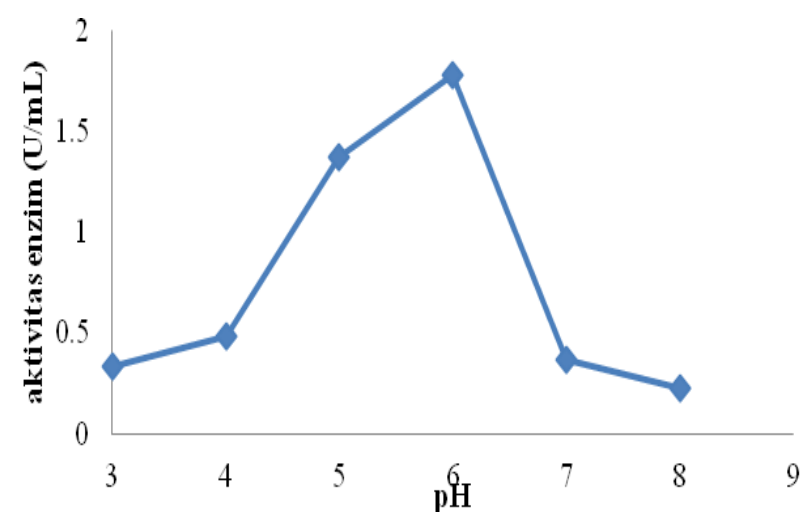

Gambar 5. Pengaruh $\mathrm{pH}$ terhadap aktivitas enzim kitinase

\section{Suhu optimum kitinase}

Selain $\mathrm{pH}$, faktor yang mempengaruhi aktivitas enzim adalah suhu. Suhu mempengaruhi energi yang diperlukan oleh enzim untuk melakukan reaksi. Peningkatan suhu dapat meningkatkan energi kinetik enzim. Jika suhu rendah maka enzim tidak memiliki cukup energi untuk melakukan reaksi sehingga tidak dapat bekerja secara optimal. Sedangkan jika pada suhu tinggi, enzim dapat terdenaturasi. Suhu dimana enzim dapat memperoleh energi yang cukup untuk bereaksi dengan optimal tanpa denaturasi disebut sebagai suhu optimum.

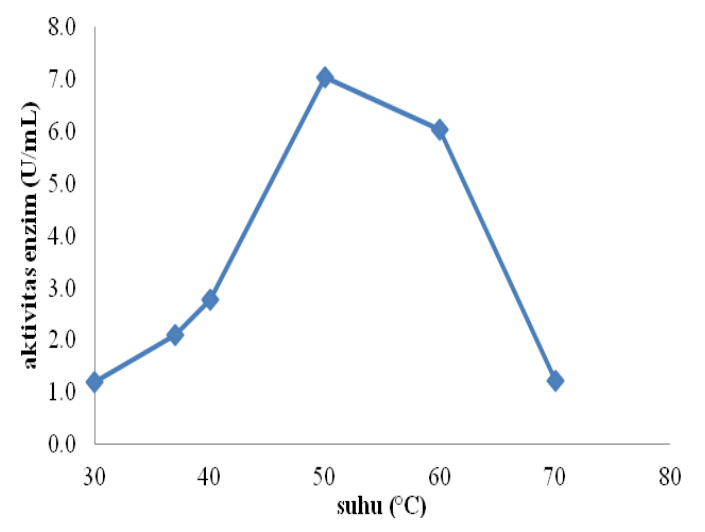

Gambar 6. Pengaruh suhu terhadap aktivitas enzim kitinase
Pengujian aktivitas kitinase $P$. pseudomallei pada berbagai suhu menunjukkan bahwa aktivitas enzim meningkat mulai dari suhu $30{ }^{\circ} \mathrm{C}$ sampai $50^{\circ} \mathrm{C}$, dan kemudian menurun pada suhu selebihnya. Kitinase mencapai aktivitas tertinggi pada suhu $50{ }^{\circ} \mathrm{C}$, yaitu sebesar $7,0329 \mathrm{U} / \mathrm{mL}$ (Gambar 6). Pada suhu optimal konformasi enzim berada dalam keadaan paling sesuai berikatan dengan substrat sehingga enzim lebih aktif dalam mengkatalisis reaksi (Wang et al, 2010).

\section{KESIMPULAN DAN SARAN}

Bakteri kitinolitik P. pseudomallei dapat diisolasi dari konsorsia mikroba pendegradasi sampah organik. Bakteri P. pseudomallei dapat menghasilkan kitinase secara optimum pada 18 jam waktu fermentasi, dengan hadirnya molase pada $0,5 \%(\mathrm{~b} / \mathrm{v})$ serta $1 \%(\mathrm{~b} / \mathrm{v})$ kitin pada media produksi. Kitinase $P$. pseudomallei memiliki aktivitas optimum pada suhu $50{ }^{\circ} \mathrm{C}$ dan $\mathrm{pH}$ 6. Pengembangan produksi kitinase dari $P$. pseudomallei perlu dilakukan melalui optimasi kadar kitin untuk memperbesar produktivitasnya.

\section{UCAPAN TERIMA KASIH}

Dana penyelenggaraan riset ini sebagian diambil dari projek Pengmas Iptek bagi Masyarakat (IbM) dari Direktorat Penelitian dan Pengabdian Kepada Masyarakat, Dikti, SK Nomor: 004/SP2H/KPM/DIT.LITABMAS/V/20 13.

\section{DAFTAR PUSTAKA}

Chern L.L, Stackebrandt, Fen Lee, Ling Lee, Kuan Chen, dan Mei Fu, 2004, Chitinibactertainanensis Gen nov., a Chitin-degrading Aerob from Soil in Taiwan, International Journal of 
Systematic

Evolutionary

Microbiology, 54: 1387-91

Dumbrepatil A, M. Adsul, Chaudhari, J. Khire, dan Gokhale, 2008, Utilization of Molasses Sugar for Lactic Acid Production by Lactobacillus delbrueckii subsp. Delbrueckii Mutant Uc-3 in Batch Fermentation, Applied and Environmental Microbiology, 74: 333-335

Herdyastuti, N., Raharjo, T.J., Mudasir dan Matsjeh, S., 2009, Chitinase and Chitinolytic Microorganism : Isolation, Characterization and potential, Indonesian Journal of Chemistry, 9 (1): 37-47

Kuddus S.M. and Ahmad R.I.Z., 2013, Isolation of novel chitinolytic bacteria and production optimization of extracellular chitinase, Journal of Genetic Engineering and Biotechnology, 11/(1): 39-46

Rostinawati, T., 2008, Skrining dan identifikasi bakteri penghasil enzim kitinase dari air laut di perairan Pantai Pondok Bali, Universitas Padjajaran : Jatinagor

Vaidya R.J., Macmil S.L., Vya,s P.R. and Chhatpar, H.S., 2003,.The novel method for isolating chitinolytic bacteria and its application in screening for hyperchitinase producing mutant of Alcaligenes xylosoxydans., Lett Appl Microbiol.36(3):129-34

Wang, S.L., Bo-Shyun, L., Liang, T.W., Wang, C.L., Pei-Chen, W. dan Je Ruei L., 2010, Purification and Characterization of Chitinase from a New Species Strain Pseudomonas sp. TKU008, Journal of Microbiology Biotechnology, 20: 1001-5

Yurnaliza, Margino, S. dan Sembiring, L., 2008, Kemampuan kitinase Streptomyces Rkt5 sebagai antijamur terhadap patogen Fusarium oxysporum, Jurnal Natur Indonesia,14(1):42-46 